\title{
PERFORMANCE EVALUATION OF DIFFERENT TYPES OF SHEAR CONNECTORS IN STEEL-CONCRETE COMPOSITE CONSTRUCTION
}

\author{
V. JAYANTHI ${ }^{1}$ C.UMARANI ${ }^{2}$
}

\begin{abstract}
Shear connectors are designed in steel-concrete composite construction to transmit the longitudinal shear, to prevent separation of steel and concrete slabs, and also to increase the structural efficiency of the whole system. In this study, the performances of different types of shear connectors in steel-concrete composite specimens are evaluated by conducting push-out tests under monotonic loading conditions. An ISMB $200 @ 25.4 \mathrm{~kg} / \mathrm{m}$ universal steel beam measuring $400 \mathrm{~mm}$ and a reinforced cement concrete slab measuring $300 \mathrm{~mm}$ with a breadth of $200 \mathrm{~mm}$ and a thickness of $200 \mathrm{~mm}$ reinforced with $8 \mathrm{~mm}$ diameter steel rods are used for the experimental study. The results reveal that the load-slip relationships for various types of shear connectors and failure mechanisms are obtained to identify those shear connectors which are more relevant to the steel - concrete composite members.
\end{abstract}

Keywords: steel-concrete composites, shear connector, push-out test, load-slip curve

\section{INTRODUCTION}

In general, the building construction via conventional method is carried out by composite elements which are comprised of two components: concrete slabs and steel beams. These two components act separately under the influence of loads since no shear transfer takes place between them. Hence, shear connectors are provided to create a bond between the beam \& the slab helping resist both tensile and shear forces. Several research projects have been carried out to evaluate the performance

\footnotetext{
${ }^{1}$ Ph.D. Scholar, Alagappa Chettiar Government College of Engineering and Technology, Karaikudi - 630 004. Tamil Nadu. Affiliated to Anna University, Chennai, Tamil Nadu, e-mail: vjayanthi me@yahoo.co.in

${ }^{2}$ Professor, Division of Structural Engineering, Department of Civil Engineering, Anna University, Chennai - 600 025, Tamil Nadu, e- mail : umarani@annauniv.edu
} 
of various shear connectors in composite structures. Ali Shariati et al. (2012) reviewed the performances of various types of shear connectors and they also discussed the advantages and disadvantages of headed studs, load capacity, bearing stress, ductility, ultimate strength, and fatigue strength of connectors used in composite structures.

Push-out experiments using headed shear studs in group arrangements were carried out by Milan Spremic et al. (2013). The strength of the concrete influences the stiffness and deformation of the connectors. A group of headed studs with reduced distance may be used instead of one largediameter single-headed stud. Abbas et al. (2011) evaluated the performance of shear studs in composite beams with steel plates and RCC slab connectors and found that the ultimate shear capacity is higher when the strength of the concrete is higher. Ali Shariati et al. (2014) evaluated the performances of angle shear connectors under monotonic and fully reversed cyclic loading in high strength concrete and found that higher ductility is observed in push-out specimens with greater angle values.

Aida Mazoz et al. (2013) investigated the behaviors of I-shape, shear connectors via push-out tests and compared the test results with existing design equations to predict ultimate load capacities. An investigation on channel shear connectors for composite concrete and T-beams was carried out by Ali Shariati et al. (2012). It is reported that channel shear capacity is lower in lightweight aggregate concrete (compared to normal concrete). The use of reinforcements in concrete slabs enhances the ductility and shear capacity of the composite system. Mahdi Shariat et al. (2011) studied shear resistance of channel shear connectors in plain, reinforced, and lightweight concrete under monotonic loading and found that an increase in the length of the channel leads to increased cracking of the concrete on the sides of the slab and also increases the ductility of the system. The performance of shear connectors in steel concrete composite slabs was studied experimentally by Swaminathan et al. (2016). It was found that headed stud connectors performed better than bolted shear connectors in terms of ultimate load-carrying capacity. Based on the above review, a parametric study was carried out on different types of shear connectors (Stud connector, Channel connector, I-connector, Sconnector and Z-connector) in this paper by conducting push-out tests on steel concrete composite specimens. The performance of the various connectors is studied via the load-slip relationships and failure mechanisms. 


\section{EXPERIMENTAL DETAILS}

\subsection{SHEAR CONNECTORS}

Five different types of shear connectors (Stud connector, Channel connector, I-connector, Sconnector, and Z-connector)are used in this experimental investigation, as shown in Fig 1.

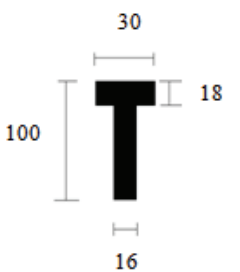

(a)

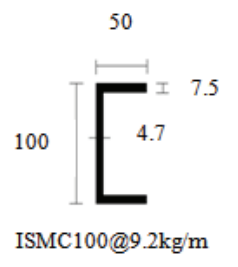

(b)

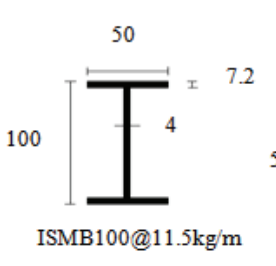

(c)

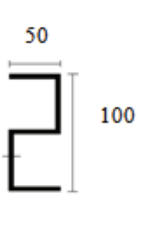

(d)

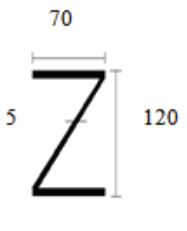

(e)

Fig 1. Different types of shear connectors: (a) Stud, (b) Channel - section, (c) I-section, (d) S-section, and (e) Z-section (All dimensions are in $\mathrm{mm}$ )

\subsection{MATERIAL PROPERTIES}

Tensile tests were conducted on several specimens (I-section) prepared from (ISMB200). Material properties such as yield stress, ultimate strength, \% elongation in length, and Young's modulus obtained from the coupon test for ISMB200 are given in Table 1. The value of yield stress, ultimate stress and \% increase in length of $8 \mathrm{~mm}$ diameter steel rod was found by conducting tensile test. The values are given in Table 1.

A tensile test was conducted on a $16 \mathrm{~mm}$ diameter mild steel rod and the values of yield stress, ultimate stress, and \% increase in length are given in Table 1.A different grade of steel was used for the shear connector. The grade of connectors is mentioned in Table 2. Ordinary grade 53 Portland cement was used. The physical properties of the cement were found by a conducting laboratory test and the values are given in Table 3.

The fine and coarse aggregates were selected per IS 383-1970 (Reaffirmed 2002), the Indian Standard Specification for Coarse and Fine Aggregates from Natural Sources for Concrete (Second Revision) for the preparation of the concrete. The physical properties of the aggregates were found by conducting tests in a laboratory environment. The values are given in Table 3.

All the concreting work was carried out in a laboratory according to IS10262:2009, the Indian Standard Concrete Mix Proportioning - Guidelines (First Revision). The concrete mix was designed 
for the M20 grade and the procedure for casting of the cubes and cylinders was done using Indian Standards. The mix proportions with the water-to-cement ratio obtained for the M20 grade of concrete are given in Table 4. A standard cylinder $150 \mathrm{~mm}$ in diameter and $300 \mathrm{~mm}$ in height and a cube 150 $\mathrm{mm} \times 150 \mathrm{~mm} \times 150 \mathrm{~mm}$ in size were simultaneously cast with the push-out specimens in order to determine the compressive strength of the concrete after a curing period of 28 days. In total, 15 cubes and 15 cylindrical specimens ( 3 specimens per connector) were cast and tested after a curing period of 28 days. The compressive strengths of the concrete for the different specimens is given in Table 5 .

Table 1. Material properties of steel beam, reinforcement, and stud connector

\begin{tabular}{|c|c|c|c|c|}
\hline Materials & $\begin{array}{c}\text { Yield stress } \\
(\mathrm{MPa})\end{array}$ & $\begin{array}{c}\text { Ultimate Strength } \\
(\mathrm{MPa})\end{array}$ & $\begin{array}{c}\text { Elongation } \\
(\%)\end{array}$ & $\begin{array}{c}\text { Young's Modulus } \\
(\mathrm{MPa})\end{array}$ \\
\hline I-Steel Beam & 275 & 505 & 21 & 208 \\
\hline $\begin{array}{c}\text { Reinforcement } \\
(8 \mathrm{~mm} \text { diameter })\end{array}$ & 225 & 370 & 23 & 210 \\
\hline $\begin{array}{c}\text { Stud Connector } \\
(16 \mathrm{~mm} \text { diameter })\end{array}$ & 425 & 485 & 14.5 & - \\
\hline
\end{tabular}

Table 2. Material properties of grade of connectors

\begin{tabular}{|c|c|}
\hline Connector & Grade $(\mathrm{MPa})$ \\
\hline Stud & 415 \\
\hline Channel & 250 \\
\hline I & 250 \\
\hline S & 250 \\
\hline$Z$ & 250 \\
\hline
\end{tabular}

Table 3. Material properties of cement, fine aggregate, and coarse aggregate

\begin{tabular}{|c|c|c|c|}
\hline $\begin{array}{c}\text { Material/ } \\
\text { Property }\end{array}$ & Cement & $\begin{array}{c}\text { Fine } \\
\text { aggregate }\end{array}$ & $\begin{array}{c}\text { Coarse } \\
\text { aggregate }\end{array}$ \\
\hline Specific Gravity & 3.10 & 2.55 & 2.66 \\
\hline Fineness Modulus & $4 \%$ & 2.33 & 6.35 \\
\hline
\end{tabular}

Table 4. Mix proportions for M20 grade concrete

\begin{tabular}{|c|c|c|c|}
\hline Water & Cement & Fine aggregate & $\begin{array}{c}\text { Coarse } \\
\text { aggregate }\end{array}$ \\
\hline $1970 \mathrm{ml}$ & $358.18 \mathrm{~kg} / \mathrm{m}^{3}$ & $748.23 \mathrm{~kg} / \mathrm{m}^{3}$ & $1114.6 \mathrm{~kg} / \mathrm{m}^{3}$ \\
\hline 0.45 & 1 & 1.89 & 3.10 \\
\hline
\end{tabular}


Table 5. Material properties of the compressive strength of the concrete

\begin{tabular}{|c|c|c|}
\hline Connector & $\mathrm{f}_{\mathrm{c}}{ }^{\prime}$ & $\mathrm{f}_{\mathrm{ck}}$ \\
\hline Headed Stud & 24.27 & 30.36 \\
\hline Channel & 23.85 & 29.91 \\
\hline $\mathrm{I}$ & 21.76 & 27.32 \\
\hline $\mathrm{S}$ & 15.63 & 19.44 \\
\hline $\mathrm{Z}$ & 13.91 & 17.39 \\
\hline
\end{tabular}

$\mathrm{f}_{\mathrm{c}}$ - Cylindrical Compressive Strength in $\mathrm{MPa}$ and $\mathrm{f}_{\mathrm{ck}}-$ Cube compressive Strength in MPa

\subsection{FABRICATION OF SPECIMENS}

The steel concrete composite push-out specimens were comprised of a steel section along with shear connectors and a reinforced cement concrete slab. The reinforced cement concrete slabs were connected to the steel beams by means of shear connectors welded to both flanges of the steel beam. The welding was strong enough to prevent failure of welding before the connector while loading. Shear connectors of similar weight $(0.9 \mathrm{~kg})$ were used in this investigation. The different types of shear connectors welded to the Universal steel I-beams are shown in Fig. 2.

The mix design of the concrete was carried out per IS 10262- 2009 for the $\mathrm{M}_{20}$ grade of concrete using locally available materials. The reinforcement was placed in the specially fabricated concrete casting mould as shown in Fig. 3 and then the freshly mixed cement concrete was placed and compacted well and left for hardening for a day. The mould was then removed and the specimen was allowed to cure for 28 days. The curing of the concrete slab on either side was done by using jute bags and after the curing period, the push out specimen looked as it is shown in Fig. 4. Two specimens were cast for each type of shear connector. After curing for 28 days, the specimens were made ready for the push-out test.
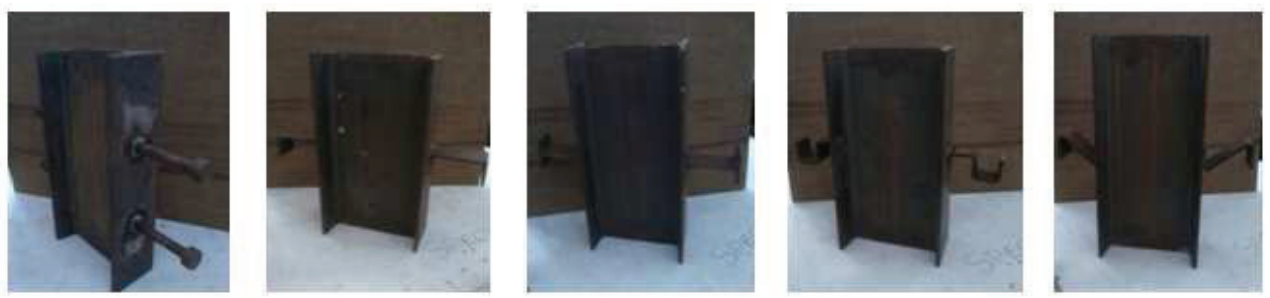

Fig 2. Shear connectors welded to the universal steel beam: (a) Stud, (b) Channel-section, (c) I-section, (d) S-section, and (e) Z-section 


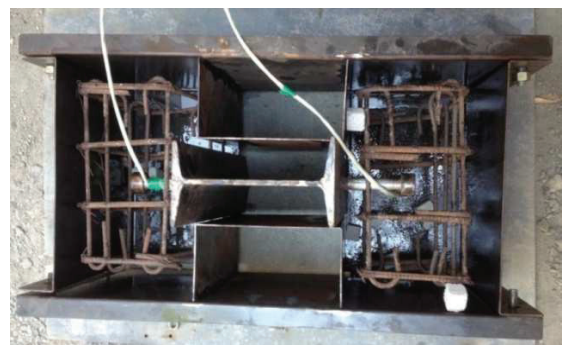

Fig 3. View of concrete casting mould with reinforcements

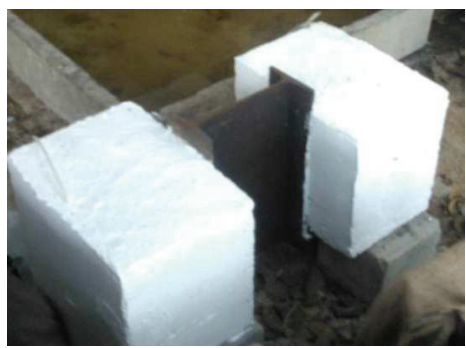

Fig 4. View of the composite specimen after curing

\subsection{PUSH-OUT SET UP AND TEST}

Push-out testing of steel concrete composite specimens was carried out to understand the behaviors of the different types of shear connectors under monotonic loading. The typical experimental setup for push-out testing is shown in Fig 5. The specimen was kept on a bearing support. Soft wooden boards were placed between the concrete slab and the base of the test frame in order to eliminate the undesirable bearing stress concentration. The model was symmetrical, with the load being carried out in the axis of symmetry, and it was assumed that the shear load per connector was equal to the total load applied divided by the number of connectors; in plotting the results, the mean value of the slips was used. A monotonic load was applied using a hydraulic actuator attached to the loading frame. The loading on the steel I-section creates heavy shearing and makes it shear off or slip from the concrete slab. The specimens were loaded till severe cracking of concrete slabs or a fracture of the shear connectors occurred. To measure the vertical slip of the I-section from the concrete slabs, two displacement transducers were instrumented on either side of the I-section. The load applied was measured using a load cell and the displacements were recorded for each increment of the loading. Push-out testing of a typical steel concrete composite specimen is shown in Fig 6. 


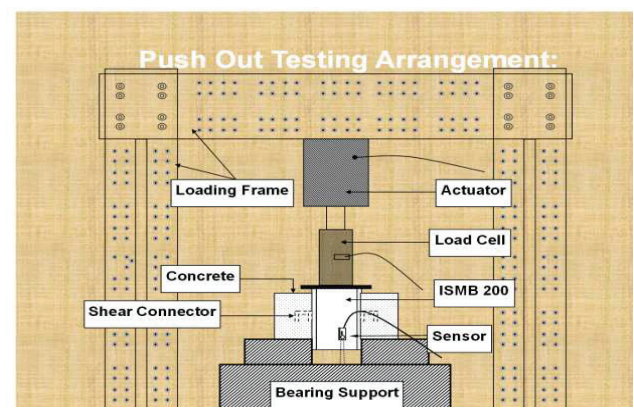

Fig 5. Typical arrangement for a push-out test

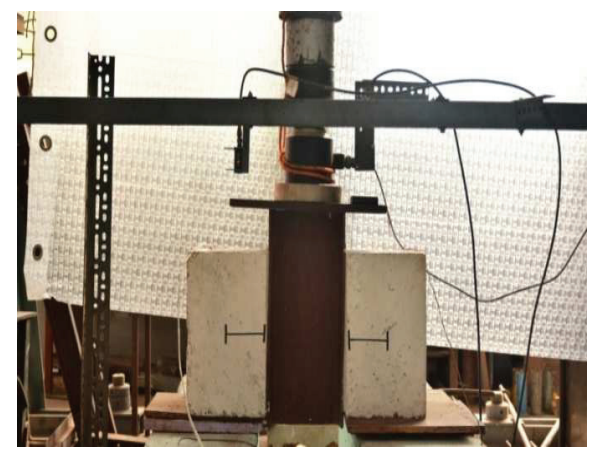

Fig 6. Steel concrete composite specimen during push-out testing

\section{OBSERVATIONS AND RESULTS}

Push-out tests were conducted on 15 steel concrete composite specimens comprised of different types of shear connectors, with 3 specimens for each type of connector. The specimens were loaded until failure occurred and a slip was recorded for every increment of the load. The value of the applied load and each measured slip is given in Table 6. 
Table 6. Loads and slips obtained from the experimental investigation

\begin{tabular}{|c|c|c|c|c|c|}
\hline \multirow{2}{*}{ Load (kN) } & \multicolumn{5}{|c|}{ Shear connector / Average slip (mm) } \\
\cline { 2 - 6 } & Stud & Channel & I & S & Z \\
\hline 0 & 0 & 0 & 0 & 0 & 0 \\
\hline 10 & 0.479 & 0.472 & 1.007 & 0.159 & 0.185 \\
\hline 30 & 0.995 & 1.128 & 1.995 & 0.69 & 0.531 \\
\hline 60 & 1.727 & 1.985 & 3.267 & 1.572 & 1.018 \\
\hline 90 & 2.391 & 2.697 & 4.951 & 2.739 & 1.584 \\
\hline 120 & 3.304 & 3.352 & 6.271 & 3.678 & 2.201 \\
\hline 150 & 3.994 & 4.098 & 7.627 & 4.563 & 2.682 \\
\hline 180 & 4.672 & 5.003 & 8.651 & 5.386 & 3.232 \\
\hline 210 & 5.087 & 5.995 & 9.683 & 6.358 & 3.839 \\
\hline 240 & 5.587 & 6.887 & 11.008 & 7.938 & 5.042 \\
\hline 270 & 6.001 & 7.558 & 12.405 & 10.086 & 6.26 \\
\hline 273 & 6.096 & 7.664 & 12.579 & 10.789 & 6.394 \\
\hline 283 & 6.228 & 8.019 & 13.159 & - & 6.841 \\
\hline 300 & 6.453 & 8.624 & - & - & - \\
\hline 330 & 6.85 & 9.726 & - & - & - \\
\hline 355 & 7.581 & 11.36 & - & - & - \\
\hline 374 & - & 12.94 & - & - & - \\
\hline
\end{tabular}

After testing of the push-out specimen with stud connectors, it is observed that the diagonal cracking of the concrete slab took place slowly and both studs failed by fracture at the stem near the fillet of the weld on one side of the beam, and another two studs remained attached to the other side of the beam with a slight deformation. The stud connectors failed by fracture at a load of $354.86 \mathrm{kN}$ with a slip of $7.581 \mathrm{~mm}$. In the case of the push-out specimen with channel connectors, it is clear that the failure of the channel at the web portion took place near the fillet of the weld on one side of the ISMB200, and no distinct bending/yielding on the other side attached to the steel beam. The maximum slip was observed as $12.94 \mathrm{~mm}$ at a load of $373.80 \mathrm{kN}$. The ultimate load-carrying capacity of the channel connector was found to be $5.3 \%$ more than that of the stud connector of the same weight.

In the I-, S-, and Z-connectors the separation of the concrete slab on one side took place due to the failure of connectors at the web portion near the fillet of the weld, and the maximum slips were recorded as $13.159 \mathrm{~mm}, 10.789 \mathrm{~mm}$, and $6.541 \mathrm{~mm}$ at loads of $282.77 \mathrm{kN}, 272.17 \mathrm{kN}$, and 282.77 
$\mathrm{kN}$, respectively, and the other side of the slab remained attached to the steel beam with no distinct bending. In all of the shear connectors, the failure mechanism was observed as a fracture of the shear connector at the web near the fillet of the weld, causing the separation of the concrete slab from the steel beam on one side, while the other side of the slab remained welded to the beam by means of a connector(with cracks). Horizontal and diagonal cracking was found in all of the shear connectors during loading, and more cracks were present in the Z-connector. Distinct bending was also observed. The typical failure of the push-out specimens is shown in Fig 7.
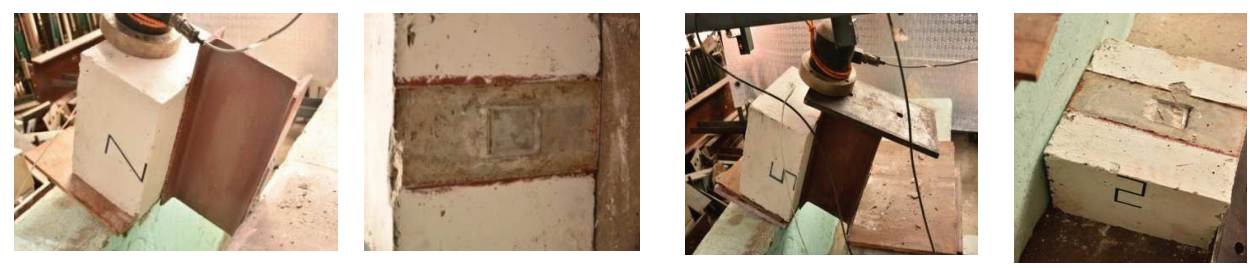

Fig.7. Typical failure of push-out specimens

The graphical representation of the load-slip values for the different types of shear connectors is shown in Fig 8. The load-slip performance of the push-out specimen with a Z-connector is linear up to $73 \%$ of the ultimate load, and that of the S-connector is linear up to $76 \%$ of the ultimate load. During the experiment, the performance of the $\mathrm{Z}$-connector and the $\mathrm{S}$-connector was found to be the same.

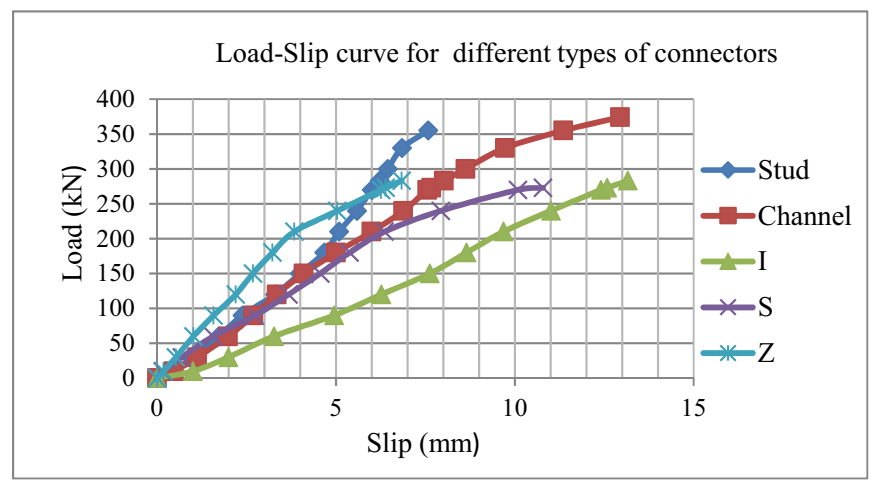

Fig 8. Load-Slip curve for different types of shear connectors

Different grades of steel were used for the connectors. In order to make a more reasonable comparison between the shear connectors, a normalized value was obtained by dividing the value of maximum force withstood by the strength of the materials results are given in Table 7. 
Table 7. Grade and normalized value of connectors

\begin{tabular}{|c|c|c|c|}
\hline Connector & $\begin{array}{c}\text { Maximum force } \\
(\mathrm{kN})\end{array}$ & $\begin{array}{c}\text { Grade of material } \\
(\mathrm{MPa})\end{array}$ & $\begin{array}{c}\text { Normalized value } \\
\text { (Max.force / Grade })\end{array}$ \\
\hline Stud & 355 & 415 & 0.855 \\
\hline Channel & 374 & 250 & 1.496 \\
\hline $\mathrm{I}$ & 283 & 250 & 1.132 \\
\hline $\mathrm{S}$ & 273 & 250 & 1.092 \\
\hline $\mathrm{Z}$ & 283 & 250 & 1.132 \\
\hline
\end{tabular}

It can be seen that the channel shear connector shows the highest normalized value, followed by the I-connector and the $\mathrm{Z}$-connector. The S-connector is withstanding the lowest applied force. Even though the headed studs withstand the highest applied force, they show a smaller normalized value due to the higher grade of steel used. The I-, S-, Z-and channel connectors are all made of the same grade of steel; out of all 4, the channel connector with stands a maximum force of $373 \mathrm{kN}$, followed by the I- and Z- connectors which both withstand $75 \%$, and the S-connector which withstands $73 \%$ of the ultimate load of the channel connector.

In this study, the weight and height of the connectors were kept as constant $(0.9 \mathrm{~kg}$ and 100 $\mathrm{mm}$, respectively) and the bearing area of the connector with the universal steel beam was also kept close to constant. In the case of the Z-connector, the width and height of the specimen were increased by $40 \%$ and $20 \%$, respectively ( $70 \mathrm{~mm}$ width and $120 \mathrm{~mm}$ height), due to fabrication difficulty. This practice led to the advantage of minimizing the vertical slip. Despite the I- and Z-connectors' ability to withstand the same ultimate force of $283 \mathrm{kN}$, with almost the same bearing area and normalized value, the maximum slip of the I-connector is 2 times higher than that of the Z-connector while failing. This shows that the vertical slip of the Z-connector is reduced by $50 \%$ due to the increase in the width and height of the connector.

Four studs of $16 \mathrm{~mm}$ shank diameter were used in this investigation. The stud connectors withstand $95 \%$ of the ultimate load of the channel connector with a vertical slip of $7.581 \mathrm{~mm}$, meaning the vertical slip is $41.25 \%$ less than the channel connector's, despite the lower normalized value.

\section{CONCLUSIONS}

1. All the specimens under investigation failed by shear only and there was no pull-off of shear connectors, ensuring good composite action of the shear connector. 
2. Horizontal and diagonal cracks were formed in the concrete and the crushing of the concrete was observed at the location surrounding the shear connector. This is due to high-bearing stresses.

3. The failure of the I-connector and the Z-connector took place at $75 \%$ of the ultimate load of the channel connector, and the failure of the S-connector took place at $73 \%$ of the ultimate load of the channel connector.

4. The channel section proved to be most effective in terms of load-carrying capacity and the I- and Z-sections were less effective when compared with the channel section, thought they performed better than the S-connector and shear studs.

\section{REFERENCES}

1. Ali Shariati, N. H. Ramli Sulong, Meldi Suhatril and Mahdi Shariati, 2012 "Various types of shear connectors in composite structures: A review”, International journal of physical sciences, Vol. 7 (22), pp. 2876-2890.

2. Milan Spremic, Zlatko Markovic, Milan Veljkovic and Dragan Budjevac, (2013) "Push-out experiments of headed shear studs in group arrangements", Advanced steel construction, Vol. 9, No. 2, pp. 139-160.

3. Mohammad Makki Abbass, Ayad S. Adi and B.S. Karkare, (2011) "Performance evaluation of shear stud connectors in composite beams with steel plate and RCC slab", International journal of earth sciences and engineering, Vol. 04, No. 6, pp. 586-591.

4. Ali Shariati, Mahdi Shariati, N.H. Ramli Sulong, Meldi Suhatril, M.M. Arabnejad Khanouki and Mehrdad Mahoutian, (2014) "Experimental assessment of angle shear connectors under monotonic and fully reversed cyclic loading in high strength concrete, Construction and building materials, Vol. 52, pp. 276-283.

5. Aida Mazoz, Abdelkader Benanane and Messaoud Titoum, (2013) "Push-out tests on a new shear connector of I-shape" International journal of steel structures, Vol. 13, No. 3, pp. 519-528.

6. Ali Shariati, N.H. Ramli Sulong, Meldi Suhatril and Mahdi Shariati, (2012) "Investigation of channel shear connectors for composite concrete and steel T-beam”, International journal of physical sciences, Vol. 7(11), pp.1828-1831.

7. Mahdi Shariati, N.H. Ramli Sulong, M.M. Arabnejad K.H, and Mehrdad Mahoutian, (2011) "Shear resistance of channel shear connectors in plain reinforced and lightweight concrete", Scientific research and essays, Vol. 6(4), pp. 977-983.

8. S. Swaminathan, A. Siva, R. Senthil and Kinson Prabu, (2016) "Experimental Investigation on Shear Connectors in Steel-concrete Composite Deck Slabs", Indian Journal of Science and Technology, Vol. 9(30), pp. 1-8.

9. D.Kisala and K.Furtak, (2016) "The Assessment of the Slip Influence on the Deflection of Steel Plate - Concrete Composite Beams”, Archives of Civil Engineering, Vol. LXII, ISSUE 2, 2016.

10. IS:11384-1985 Indian Standard Code of Practice for Composite Construction in Structural Steel and Concrete.

11. IS 10262:2009 Indian Standard Concrete Mix Proportioning - Guidelines (First Revision).

12. IS 383-1970 (Reaffirmed 2002), Indian Standard Specification for Coarse and Fine aggregates from Natural sources for Concrete (Second Revision). 


\section{LIST OF FIGURES AND TABLES:}

Fig. 1 Different types of shear connectors

Rys. 1 Różne rodzaje kotwic do betonu

Fig. 2 Shear connectors welded to the universal steel beam

Rys. 2 Kotwice do betonu przyspawane do uniwersalnej stalowej belki

Fig. 3 View of concrete casting mould with reinforcement

Rys. 3 Widok formy do odlewania betonu ze zbrojeniem

Fig. 4 View of composite specimen after curing

Rys. 4 Widok złożonej próbki po utwardzeniu

Fig. 5 Typical arrangement for push - out test

Rys. 5 Typowy układ do testu wypychania

Fig. 6 Steel concrete composite specimen during push-out testing

Rys. 6 Złożona próbka stalowo-betonowa podczas testu wypychania

Fig. 7 Typical failure of push-out specimens

Rys. 7 Typowe zniszczenie wypychanych próbek

Fig. 8 Load -Slip curve for different types of shear connectors

Rys. 8 Krzywa obciążenia i poślizgu dla różnych rodzajów kotwic do betonu

Tab. 1 Material properties of steel beam, reinforcement and stud connector

Tab. 1 Właściwości materiałowe stalowej belki, zbrojenia i sworznia łącznikowego

Tab. 2 Material properties of grade of connectors

Tab. 2 Właściwości materiałowe rodzaju kotwic

Tab. 3 Material properties of cement, fine aggregate and coarse aggregate

Tab. 3 Właściwości materiałowe cementu, drobnego kruszywa oraz gruboziarnistego kruszywa

Tab. 4 Mix proportion for M20 grade of concrete

Tab. 4 Proporcje mieszaniny dla betonu klasy M20

Tab. 5 Material properties of compressive strength of concrete

Tab. 5 Właściwości materiałowe dla wytrzymałości betonu na ściskanie

Tab. 6 Load and slip measured from the experimental investigation

Tab. 6 Obciążenie i poślizg mierzone w badaniu eksperymentalnym

Tab. 7 Grade and normalized value of connectors

Tab. 7 Klasa i znormalizowana wartość kotwic 


\section{OCENA OSIĄGÓW RÓŻNYCH RODZAJÓW TRZPIENI W KONSTRUKCJACH ZESPOLONYCH}

Słowa kluczowe: kompozyty stalowo-betonowe, kotwica do betonu, badanie wypychania, krzywa obciążenia i poślizgu

\section{STRESZCZENIE:}

Element konstrukcyjny złożony z dwóch lub większej ilości różnych rodzajów materiałów połączonych ze sobą, aby zachowywać się strukturalnie jako jedna jednostka, nosi nazwę elementu złożonego. W złożonych elementach stalowo-betonowych, wzdłużna siła ścinająca jest przenoszona na powierzchnię przylegania pomiędzy stalowym kołnierzem i płytą betonową, w wyniku mechanicznego działania kotwic do betonu. Zdolność kotwic do betonu do przenoszenia wzdłużnych sił ścinających zależy od ich wytrzymałości oraz od wytrzymałości płyty betonowej na pękanie podłużne, wywołane wysokim stężeniem sił ścinających. Stąd, te kotwice do betonu muszą być zaprojektowane tak, aby przenosić podłużne ścinanie wzdłużne wzdłuż powierzchni przylegania elementów stalowych i betonowych, w celu zapobieżenia separacji belki stalowej i płyty betonowej na styku oraz zwiększenia efektywności strukturalnej całego układu.

W niniejszym artykule omówiono ocenę wydajności różnych rodzajów kotwic do betonu w ramach przeprowadzonych testów wypychania próbek kompozytu stalowo-betonowego. Zaproponowano zastosowanie wypchniętej próbki kompozytu stalowo-betonowego z wykorzystaniem uniwersalnej stalowej belki ISMB200 o długości $400 \mathrm{~mm}$ i zbrojonego betonowego bloku o wymiarach $300 \mathrm{~mm}$ x $200 \mathrm{~mm}$ i grubości $200 \mathrm{~mm}$ z różnymi rodzajami kotwic do betonu, takimi jak sworzeń łącznikowy, kanał, element I, element S i element Z. Bloki betonowe zostały przymocowane do kołnierzy stalowej belki za pomocą przyspawanych kotwic do betonu. Próbki ze sworzniem łącznikowym z łbem zostały wykonane przy użyciu dwóch sworzni na każdy kołnierz, a pozostałe rodzaje zostały wykonane przy użyciu jednego łącznika na każdy kołnierz.

W przypadku kotwic do betonu, zastosowano dwa różne rodzaje stali, takie jak Fe250 i Fe415. Łącznie wylano i przetestowano 15 wypychanych próbek kompozytu stalowo-betonowego, tj. 3 próbki dla każdego rodzaju łącznika, składającego się z różnych rodzajów kotwic do betonu. Ciężar, wysokość i powierzchnia nośna kotwic do betonu przyspawanych do stalowej belki zostały utrzymane na stałym poziomie. Test został przeprowadzony w stanie monolitycznego obciążenia aż do awarii i podczas awarii zaobserwowano zniszczenie próbki.

Ponieważ dla łączników zastosowano różne gatunki stali, uzyskano znormalizowaną wartość dla rozsądnego porównania. Z badań eksperymentalnych wynika, że kotwica do betonu w kanale posiada najwyższą znormalizowaną wartość, a następnie łącznik I i łącznik Z. Łącznik S jest w stanie wytrzymać najmniejszą siłę. Mimo, że sworznie z łbem wytrzymują najwyższą siłę, posiadają mniejszą znormalizowaną wartość ze względu na wyższy gatunek stali. I, S, Z oraz łączniki kanałowe są wykonane z tego samego gatunku stali i spośród 4 łączników, łącznik kanałowy wytrzymuje maksymalną siłę o wartości 373 kN, a następnie łącznik I i łącznik Z. Łączniki I i Z wytrzymują 75\%, a łącznik S wytrzymuje $73 \%$ całkowitego obciążenia łącznika kanałowego.

W niniejszym badaniu eksperymentalnym, ciężar i wysokość łączników są utrzymywane odpowiednio na poziomie $0,9 \mathrm{~kg}$ i $100 \mathrm{~mm}$, a powierzchnia nośna łącznika z uniwersalną belką stalową jest również utrzymywana na stałym poziomie. W przypadku łącznika Z, szerokość i wysokość próbki została zwiększona odpowiednio o 40\% i 20\%, tj. $70 \mathrm{~mm}$ szerokości i $120 \mathrm{~mm}$ wysokości, z powodu trudności w produkcji. Praktyka ta przyniosła korzyść w postaci zminimalizowania pionowego poślizgu. Pomimo, że łącznik I i łącznik Z wytrzymują tę samą siłę końcową, tj. $283 \mathrm{kN}$, 
mają one taką samą powierzchnię nośną i taką samą znormalizowaną wartość, a maksymalny poślizg łącznika I jest dwa razy większy niż w przypadku złącza $Z$ podczas awarii. Pokazuje to, że pionowy poślizg łącznika Z zmniejsza się o 50\% ze względu na wzrost szerokości i wysokości łącznika. W tym badaniu zastosowano cztery sworznie o średnicy łba wynoszącej $16 \mathrm{~mm}$. Sworznie łącznikowe wytrzymują 95\% całkowitego obciążenia łącznika kanałowego z pionowym poślizgiem wynoszącym $7,581 \mathrm{~mm}$, co oznacza, że pionowy poślizg jest $41,25 \%$ mniejszy niż w przypadku łącznika kanałowego, pomimo niższej znormalizowanej wartości.

Z badania eksperymentalnego wynika, że:

I) Wszystkie badane próbki zostały zniszczone wyłącznie podczas ścinania i nie nastąpiło zerwanie kotwicy do betonu, co zapewnia dobre działanie kompozytowe kotwicy do betonu.

II) $\quad \mathrm{W}$ betonie powstały poziome i skośne pęknięcia i zaobserwowano kruszenie betonu w miejscu otaczającym kotwicę do betonu. Jest to spowodowane wysokimi naprężeniami łożysk.

III) Awaria łącznika I i łącznika Z wystąpiła przy końcowym obciążeniu łącznika kanałowego na poziomie 75\%, a awaria łącznika S nastąpiła przy końcowym obciążeniu łącznika kanałowego na poziomie 73\%.

IV) Przekrój kanału okazał się być najbardziej skuteczny pod względem nośności, a element I i element $\mathrm{Z}$ okazały się mniej skuteczne w porównaniu z przekrojem kanału, lecz osiągnęły lepsze wyniki niż łącznik S i sworznie ścinające. 